Article

\title{
A System Engineering Approach Using FMEA and Bayesian Network for Risk Analysis-A Case Study
}

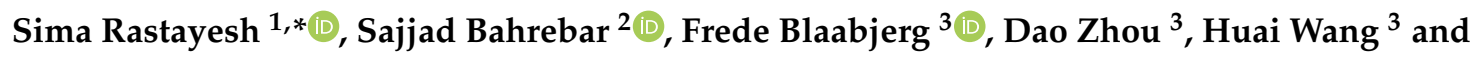 \\ John Dalsgaard Sørensen ${ }^{1}$ (i) \\ 1 Department of Civil Engineering, Aalborg University, 9000 Aalborg, Denmark; jds@civil.aau.dk \\ 2 Department of Mechanical Engineering, Technical University of Denmark, 2800 Kongens Lyngby, Denmark; \\ sajbahr@mek.dtu.dk \\ 3 Department of Energy Technology, Aalborg University, 9000 Aalborg, Denmark; fbl@et.aau.dk (F.B.); \\ zda@et.aau.dk (D.Z.); hwa@et.aau.dk (H.W.) \\ * Correspondence: sir@civil.aau.dk
}

Received: 24 November 2019; Accepted: 17 December 2019; Published: 20 December 2019

\begin{abstract}
This paper uses a system engineering approach based on the Failure Mode and Effect Analysis (FMEA) methodology to do risk analysis of the power conditioner of a Proton Exchange Membrane Fuel Cell (PEMFC). Critical components with high risk, common cause failures and effects are identified for the power conditioner system as one of the crucial parts of the PEMFCs used for backup power applications in the telecommunication industry. The results of this paper indicate that the highest risk corresponds to three failure modes including high leakage current due to the substrate interface of the metal oxide semiconductor field effect transistor (MOSFET), current and electrolytic evaporation of capacitor, and thereby short circuit, loss of gate control, and increased leakage current due to gate oxide of the MOSFET. The MOSFETs, capacitors, chokes, and transformers are critical components of the power stage, which should be carefully considered in the development of the design production and implementation stage. Finally, Bayesian networks (BNs) are used to identify the most critical failure causes in the MOSFET and capacitor as they are classified from the FMEA as key items based on their Risk Priority Numbers (RPNs). As a result of BNs analyses, high temperature and overvoltage are distinguished as the most crucial failure causes. Consequently, it is recommended for designers to pay more attention to the design of MOSFETs' failure due to high leakage current owing to substrate interface, which is caused by high temperature. The results are emphasizing design improvement in the material in order to be more resistant from high temperature.
\end{abstract}

Keywords: bayesian network; failure mode and effect analysis; proton exchange membrane fuel cell; power conditioner; risk analysis

\section{Introduction}

Global climate changes caused by conventional energy resources such as fossil fuels are one of the dominant motivations that engineers are trying to employ renewable energies. Also, fossil fuel resources are limited, and they will eventually be depleted with the rapid growth of energy consumption. The environmental damages in the world caused by non-renewable energies ends up to be approximately five trillion dollars per year [1]. Renewable energies, such as wind turbines, solar cells and fuel cell systems are proposed as solutions to solve these global problems. A fuel cell works as a source generating energy along with unique properties, which are being developed rapidly. In the global sustainable development perspective, fuel cells are suitable as they provide high energy conversion efficiency, various usages being a compact and environmental friendliness system. These are the foremost reason that fuel cell systems are used in energy systems; that is why they are 
considered as one of the main sources of energy. The first fuel cell was demonstrated by a Welsh scientist and barrister William Grove in 1839. One type of fuel cells was improved by General Electric in the beginning of 1960s [2] which was the Proton-Exchange Membrane Fuel Cells (PEMFC) which are a kind of fuel cells, which are being developed mainly for transportation and portable applications and even in hybrid energy systems such as wind-fuel cell systems. High energy efficiency, less pollution, and high reliability are significant properties of the PEMFC systems [3]. The telecommunication industry has applied fuel cell systems for backup power [4]. Under this circumstance, availability and reliability, as well as risk, are important issues, which should be assessed carefully for them. PEMFC technology has been developed to overcome the instability and environmental concerns compared with conventional energy sources since the 1990s. Fuel cells are relatively expensive, having a higher cost, one ought to identify the high risk components to spend more money on their design to minimize the cost of failures. Failure Mode and Effect Analysis (FMEA), an organized technique for failure analysis, is applied to identify critical failure modes, failure causes, and effects of the items of interest, which can be applied for power electronics.

The risk is a measure of the potential expected loss occurring due to natural or non-natural activities [5]. Risk analysis has two facets: Quantitative and qualitative. In order to assess probabilities to make decisions, the quantitative risk analysis endeavor to estimate the risk in the form of probability (frequency) of a loss. Quantitative risk analysis is frequently a preferred approach when adequate field data, test data, and other evidence are available to estimate the likelihood and magnitude of the losses [6-9]. Qualitative risk analysis is the most widely used since it is quick and straightforward to perform. For this type, the potential loss is qualitatively estimated using linguistic scales such as low, medium, and high. Since this type of analysis barely needs to rely on actual data and its probabilistic treatment, the analysis is much simpler and easier to use and understand; however, it may be rather subjective [10].

FMEA is a structured and logical methodology for identifying, analyzing and ranking estimated risk having various potential failure modes. Furthermore, it is suggested to improve the methodology; for instance, changes in the design or control tests, which can assist engineers to prevent the failure or reduce its effects [11]. FMEA is a vital reliability tool to identify critical failure modes, failure causes, and failure mechanisms that can be used to diagnose probable failure and dissatisfactions of functions for any items in a system before they occur, aiming to reduce their risks [12].

The FMEA method is based on discovering, arranging, and decreasing the failures or faults; moreover, it has been used in multiple kinds of industry [13]. For instance, FMEA can be used for energy production systems such as wind turbines consisting of a complex system of electrical, mechanical and structural components [14]. Three risk factors, including Occurrence (O), Detectability (D), and Severity (S) are used in the FMEA. O designates the rate of the risks, D point to the likelihood of risks prediction earlier than their occurrence, and $S$ is the significance of the risk to the system. The yield factor indicated as the Risk Priority Number (RPN) is the creation of the three input parameters grade the failure state which are scored by a 10-point scale. As a matter of fact, RPN is a quantitative and qualitative risk analysis in the form of numerical ranking of risk of each potential failure mode. It is constitued of the product of the three qualitative factors, $\mathrm{S}$ of the effect, likelihood of $\mathrm{O}$ of the cause, and likelihood of D of the cause in the robustness method [15]. Many standards are used to classify different faults, which occur in the PEMFC. In this paper, scales are extracted from the Automotive Industry Action Group (AIAG). Afterwards, by multiplying these input factors, their corresponding RPNs are recognized [16].

The reliability and availability of the PEMFC system, especially power conditioner, are vital in the condition of power grid outage used in the telecommunication stations backup power. Owing to that factor, risk assessment and failure effect analysis of the critical components are mandatory. There are several research studies available, which perform the FMEA for fuel cell systems with the emphasis on the fuel cell stack [17]. However, the means to implement the FMEA is not given or provided; thus, it is not given how this procedure is implemented by using either brain-storming or a system engineering 
approach. In this paper, two aspects are combined to fulfill the gap in the existing literature. First, instead of focusing on the fuel cell stack, the power conditioner is comprehensively investigated, which are studied in terms of the critical power electronics components. Second, the FMEA is implemented based on system engineering approach having the given detailed implementation procedure.

Furthermore, Bayesian Network (BN) is utilized to analyze the most critical failure causes among more important items identified from FMEA. BN is a graphical model that containing nodes, symbolizing variables, and directed links between them standing for casual relationships. The relationships between variables are as if $X$ causes $Y, X$ is a parent of $Y$, and $Y$ is a child of $X$. The probabilities are given as conditional probability distributions for each node, depending on the parents. When evidence is received for a node, the joint distribution can be updated using Bayes rule, and posterior marginal distributions can be found [18]. This will help designers to pay more attention on the development of the design for instance, material properties to avoid failures from obtained results by this method. For example, anion-deficient perovskites, as materials with high ionic conductivity and a wide range of temperature stability, are very suitable for fuel cell membranes [19]. Moreover, magneto dielectrics such as hexaferrites: are the materials that are promising for the production of capacitors, which are very necessary for their stable operation [20]. For the stable and steady operation of modern power plants and uninterruptible power systems, it is necessary to provide for their protection against unwanted external electromagnetic radiation. Such an electromagnetic effect can easily cause the collapse of the entire modern energy system. To prevent this, electromagnetic shields must be used [21,22].

To sum up, by using the FMEA for the PEMFC system, potential failure modes and risk of components are identified, and critical components are also classified. Furthermore, the potential of the risk priority number is assigned to any failure. The FMEA results offer which component is critical to have high RPNs. Moreover, some recommended solutions are suggested to create better conditions to reduce their risk. Therefore, damage to the entire system due to failure modes and causes is decreased. Finally, by implementing BN the impact of each failure cause is studied, to find which failure causes have the most effects among other failure causes in the MOSFET.

\section{Description of PEMFC and Power Conditioner}

\subsection{PEMFC System}

A PEMFC is an electrochemical system, which changes the chemical energy through the reaction of hydrogen and oxygen to electrical power. There are a variety of PEMFC applications such as mobile power generation systems and stations, automotive, aerospace and marine industries [23].

A typical configuration of the PEMFC system is shown in Figure 1, which consists of the Balance of Plant (BoP), the PEMFC stack, and the power conditioner. $[7,8]$. The BoP is a monitoring system having auxiliary parts, which serve to regulate the supply and balance hydrogen, air, water and thermal condition for the PEMFC stack. The PEMFC stack is an assembly of several single cells (output less than $1 \mathrm{~V}$ ), bipolar plates, cooling plates, end plates, bolts, and gaskets, which converts the chemical energy into the electricity [23]. A power conditioner is composed of active and passive electrical components, enabling to regulate the fixed output from the PEMFC stack [24].

\subsection{Power Conditioner Sub-System}

This section presents the detailed configuration of the power conditioner sub-system for a PEMFC system in a backup power application. The block diagram of the power conditioner sub-system having $1 \mathrm{~kW}$ output power is shown in Figure 2, where five parts, are included which are the power stage, auxiliary power supply, gate driver, controller, and $\mathrm{PCB}$, which can be further sub-divided [25]. The power stage consists of an isolated DC/DC converter. This part contains plenty of components (such as MOSFETs, capacitors, inductors, transformer, and other related components). The input voltage range is 30-65 V, while the output voltage is $48 \mathrm{~V}$. As a result, a power converter that can work both in step-up 
and step-down modes is preferred. Moreover, the isolation from primary-side and secondary-side is required according to the industry standard. Some of the functions of the subsystems are switching the electrical current at the desired time interval, rectifying current in the desired time interval and control, regulating and rectifying the electrical current and voltage level change.

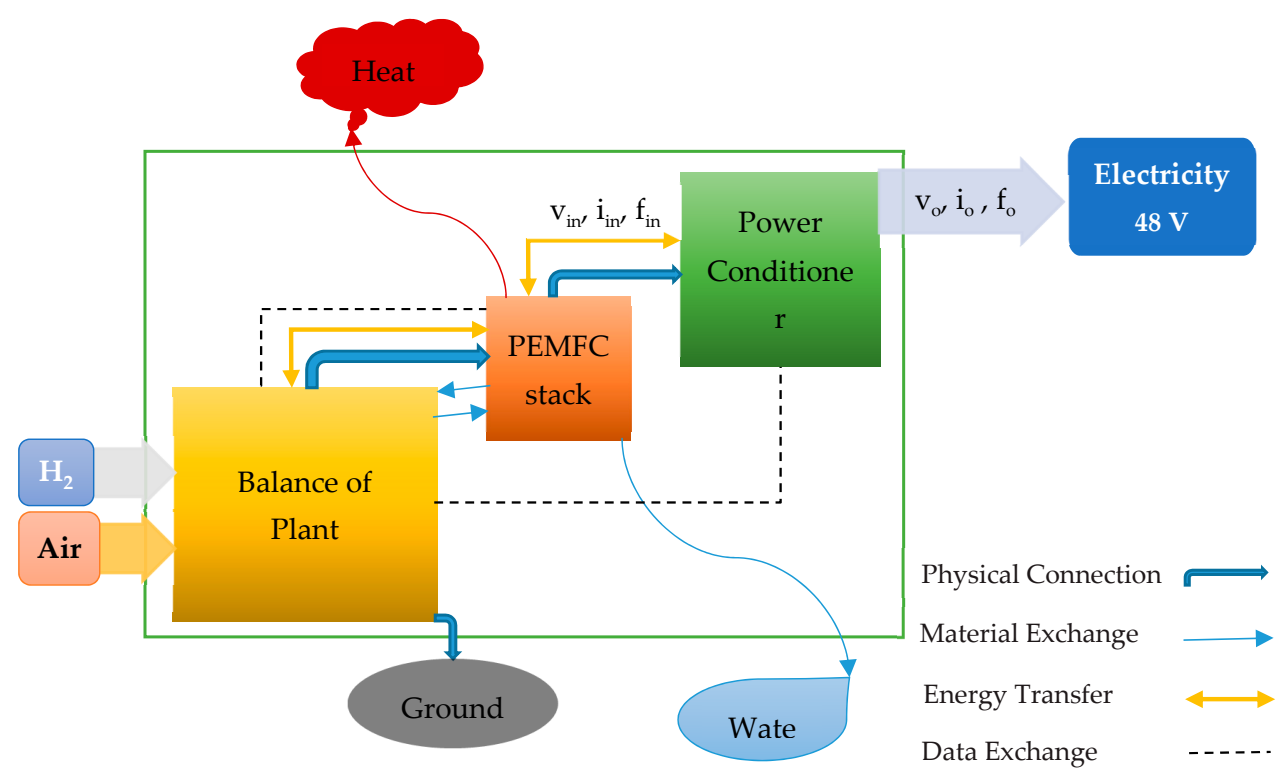

Figure 1. Block diagram of a typical PEMFC system used in a backup power application.

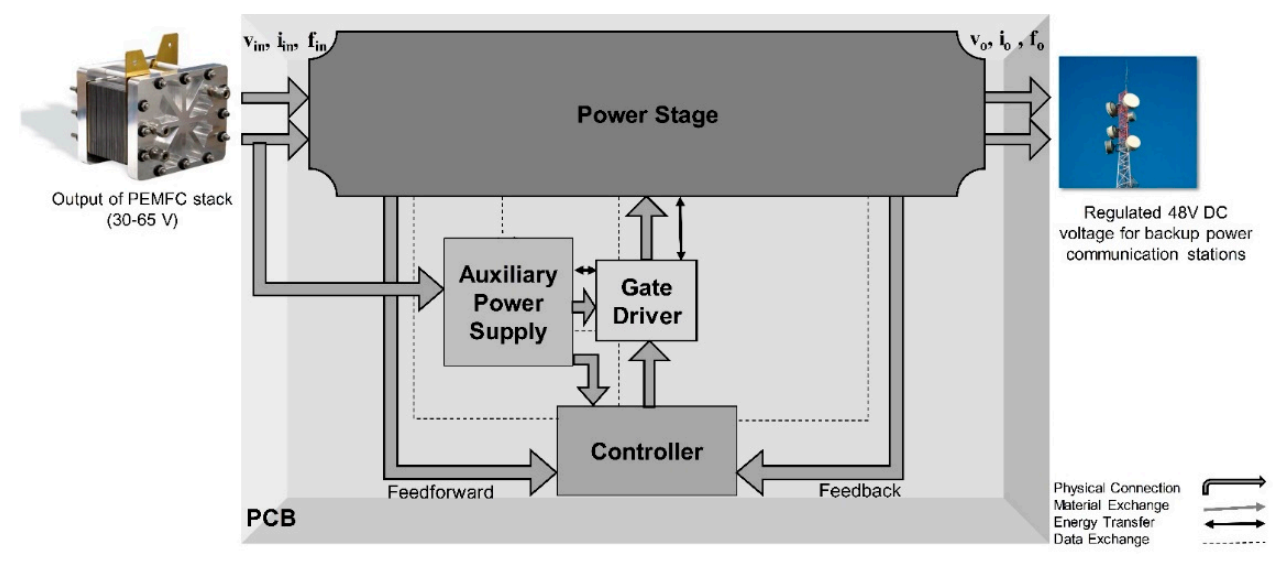

Figure 2. Block diagram of power conditioner (DC/DC converter).

In the power stage, eight primary and eight secondary MOSFETs are used as active switches having the function to control the electrical current in the system. Also, eight primaries and eight secondary diodes are applied in the converter. Moreover, two transformers are used to provide isolation between primary and secondary side. Besides, here are eight electrolytic capacitors having a capacity of $680 \mu \mathrm{F}$ and $63 \mathrm{~V}$ in the primary and six electrolytic capacitors having the capacity of $390 \mu \mathrm{F}$ and $100 \mathrm{~V}$ in the secondary side as a storage for the electrical energy and stabilization of the dc voltage. The overall objective of the power conditioner is that in the case of a step-up mode, the primary-side inductor is charged by the activation of all transistors; while it is discharged by the parallel connection of the two transformers. Alternatively, in the case of the step-down mode, the primary-side inductor is charged by the parallel connection of the transformers, while it is discharged by the series connection of the transformers [26]. The structure of the power converter used in this study is presented in Figure 3. Due to the variable output voltage of the fuel cell stack, a dc/dc power converter is required to match the voltage in telecom applications. A topology using galvanic isolation is shown in Figure 3, where 
the rated power of the converter is $1 \mathrm{~kW}$, and six $1 \mathrm{~kW}$ converters are connected in parallel for a $5 \mathrm{~kW}$ power stage to obtain the redundancy. Moreover, a synchronous rectification is adopted to achieve low conduction losses in the situation of low-voltage and high-current at the secondary-side of the transformer [26]. All the components in the power conditioner can be categorized of four levels of the PEMFC system as it is demonstrated in Figure 4.

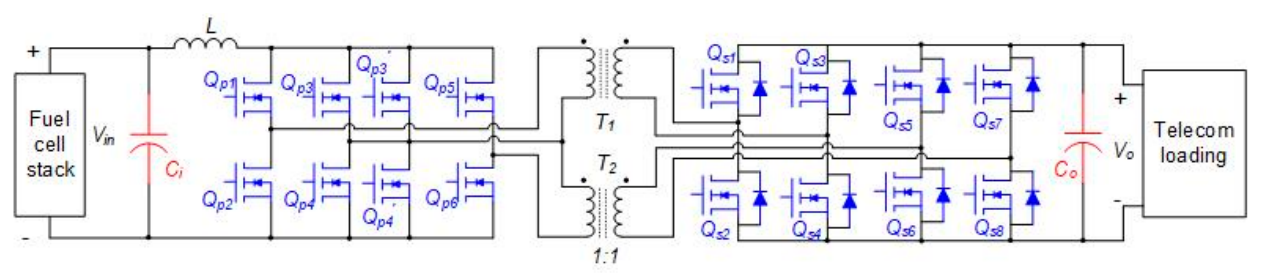

Figure 3. Structure of the power converter [26].

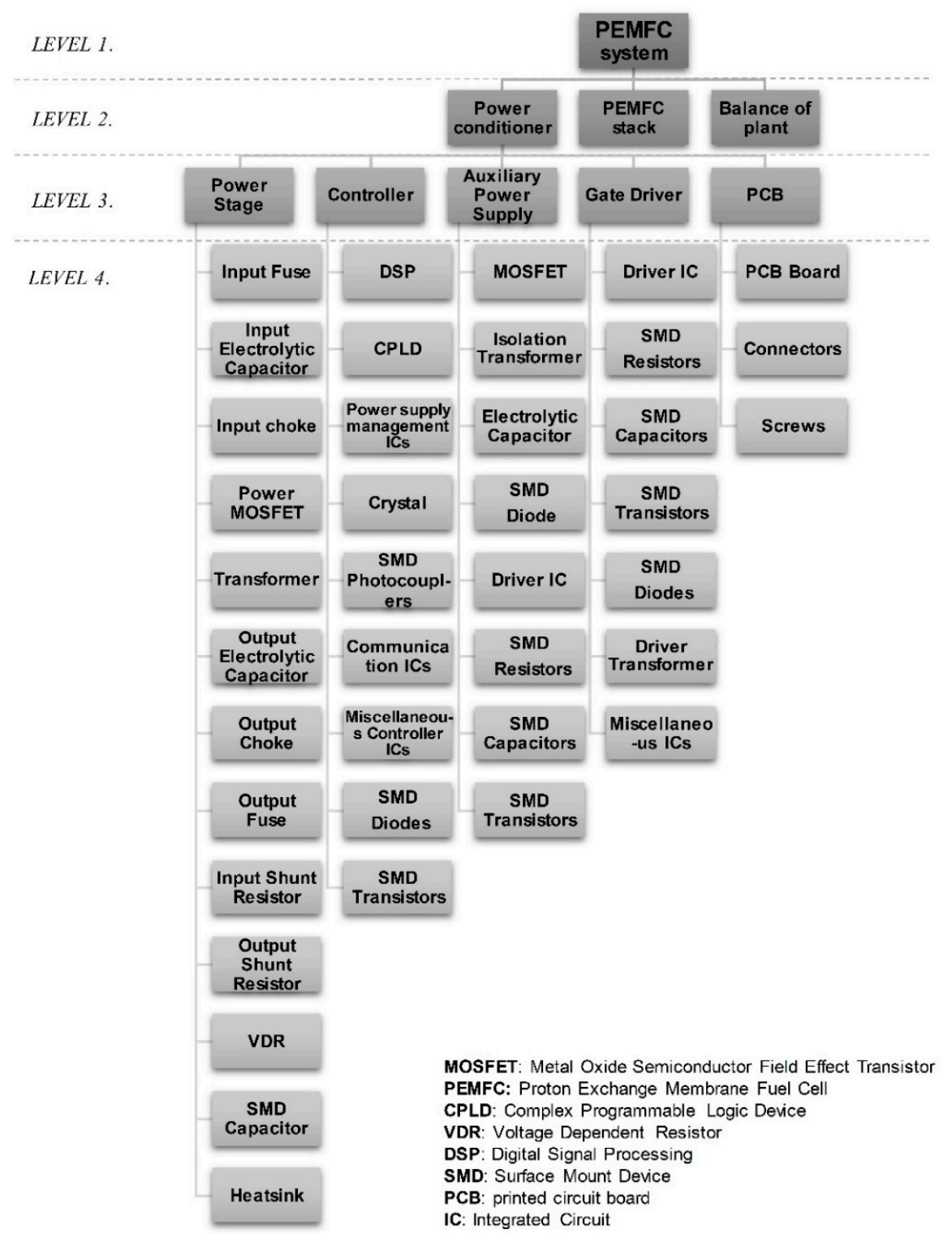

Figure 4. Four levels of PEMFC system along with all the main components and sub-components in the power conditioner. 


\section{System Engineering Approach Based FMEA of Power Conditioner}

\subsection{Boundary Diagram and FMEA Interface Matrix}

In order to make a visible scope of the FMEA analysis, an FMEA block diagram (FMEA boundary diagram) is used to visualize the interfaces between the various sub-systems and components. The boundary diagram shows the physical and logical relationships among the main sub-systems of the PEMFC system, such as physical connection, material exchange, energy transfer, and data exchange. Besides, their inputs and outputs are also identified [3] (Figures 1 and 2 illustrate an overview of boundary diagram for the PEMFC system and the power conditioner sub-system). Moreover, the FMEA interface matrix is a chart on the vertical and horizontal axes interfaces, which ought to be considered in the examination of this kind of interface. As aforementioned, the physical connection, material exchange, energy transfer, and data exchange are four primary types of interfaces. Up to $50 \%$ or more of the total failures are normally seem in the interfaces. As a result, it is important that any FMEA considerately study the interfaces between the sub-systems and components besides their content. On top of the FMEA boundary diagram, as a complementary to it, the FMEA interface matrix is presented. The FMEA interface matrix for the PEMFC system is listed in Table 1 in connection with Figure 1; and the FMEA interface matrix for the power conditioner is listed in Table 2 and is related to Figure 2.

Table 1. FMEA interface matrix for three main systems of PEMFC.

\begin{tabular}{cccc}
\hline PEMFC & Balance of Plant & PEMFC Stack & Power Conditioner \\
\hline $\begin{array}{c}\text { Balance of plant } \\
\text { PEMFC stack } \\
\text { Power conditioner }\end{array}$ & PMED1 & PMED1 & PE1 \\
\hline $\begin{array}{l}\text { Interface Type: Physical (P), Material Exchange (M), Energy Transfer (E), Data Exchange (D); Functional Necessity: } \\
\text { Must be present (1), Must not be present (2). }\end{array}$ &
\end{tabular}

Table 2. FMEA interface matrix for the power conditioner.

\begin{tabular}{cccccc}
\hline Power Conditioner & $\begin{array}{c}\text { Auxiliary Power } \\
\text { Supply }\end{array}$ & Power Stage & Controller & Gate Driver & PCB \\
\hline Auxiliary Power Supply & & PED1 & PD1 & PED1 & P1 \\
Power Stage & PED1 & & & PED1 & P1 \\
Controller & PD1 & PED1 & PD1 & PD1 & P1 \\
Gate Driver & PED1 & P1 & P1 & P1 & P1 \\
PCB & P1 & P & &
\end{tabular}

\subsection{Function Block Diagram and Parameter Diagram}

Another visual tool to describe the operation, interrelationships and interdependencies of the system functions is Function Block Diagram (FBD). Moreover, the Parameter diagram (P-diagram) is a functional tool to document input signals, noise factors, control factors, error states, and ideal response. It is more practical once the item under analysis is a complicated system where it is a time-consuming analysis; however, it can provide significant value in comprehending and controlling the system and recognizing the input to the FMEA techniques. Any of these tools are used for better detection of the FMEA of the four levels of classifications of the PEMFC system [27]. FBD of the PEMFC system is shown in Figure 5. Furthermore, the P-Diagram (PD) of the PEMFC is illustrated in Figure 6, which takes the inputs from a system and link those inputs to the desired outputs. In addition, it considers non-controllable influences from outside. 


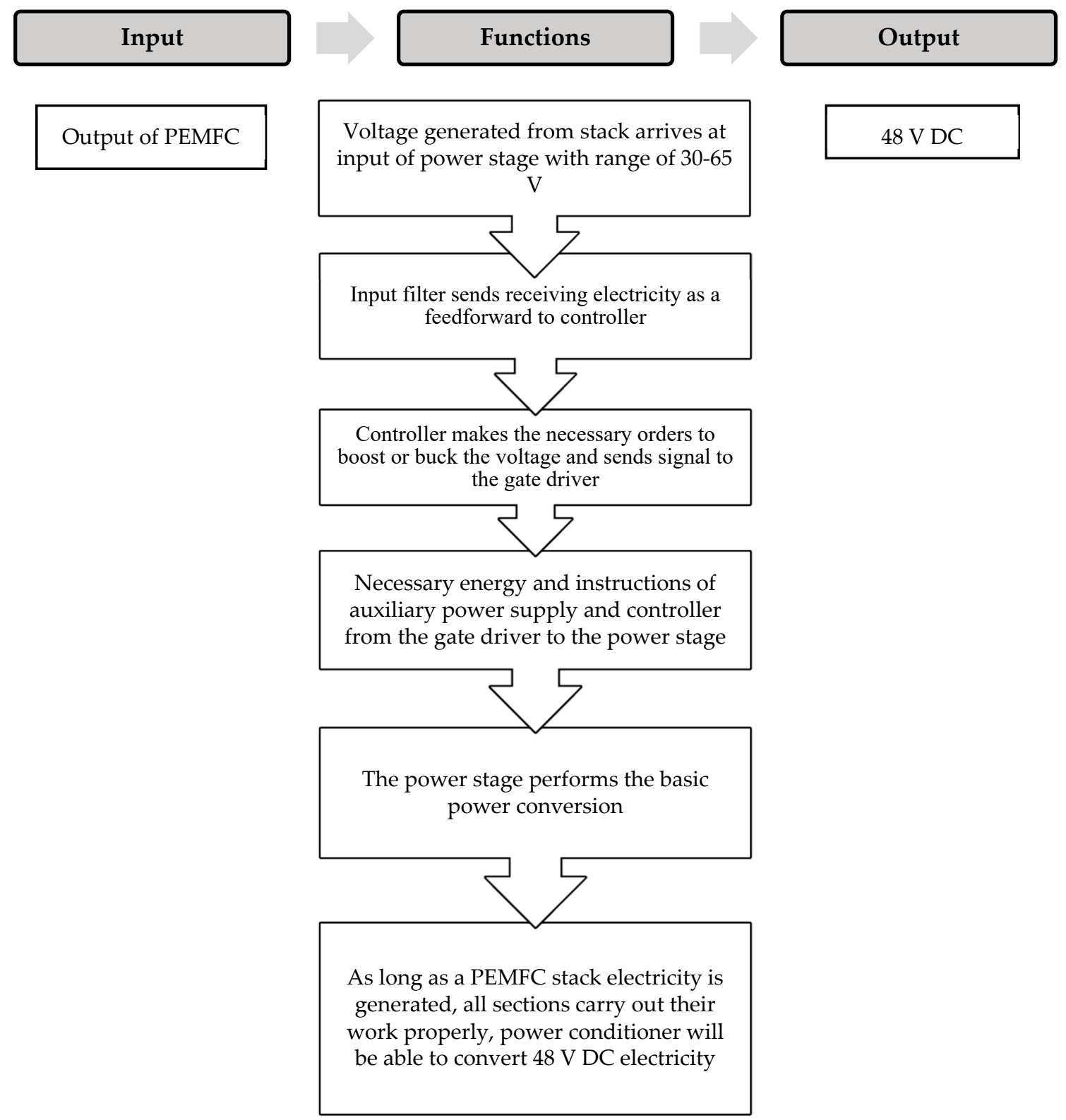

Figure 5. Function block diagram of the power conditioner.

\subsection{Relationship of Functions and Failure Modes}

As mentioned before, it is important that a FMEA precisely investigates the connective links among the sub-systems and components as well as their content. As shown in Figure 7, four levels of the PEMFC system are used to describe the power stage, which contains four critical components: MOSFETs, electrolytic capacitors, transformers and inductors (chokes). Generally, any failure mode is a failure cause for the power stage (Level 3). Similarly, failure modes of the power stage (Level 3) are failure causes of the power conditioner (Level 4). Figure 7 demonstrates the hierarchical impact of the failure of the PEMFC and interfaces among system, sub-system, and principal components. Two primary functions (F) and failure modes (FM) of the power conditioner and their relations with three levels are shown in Figures 8 and 9. 


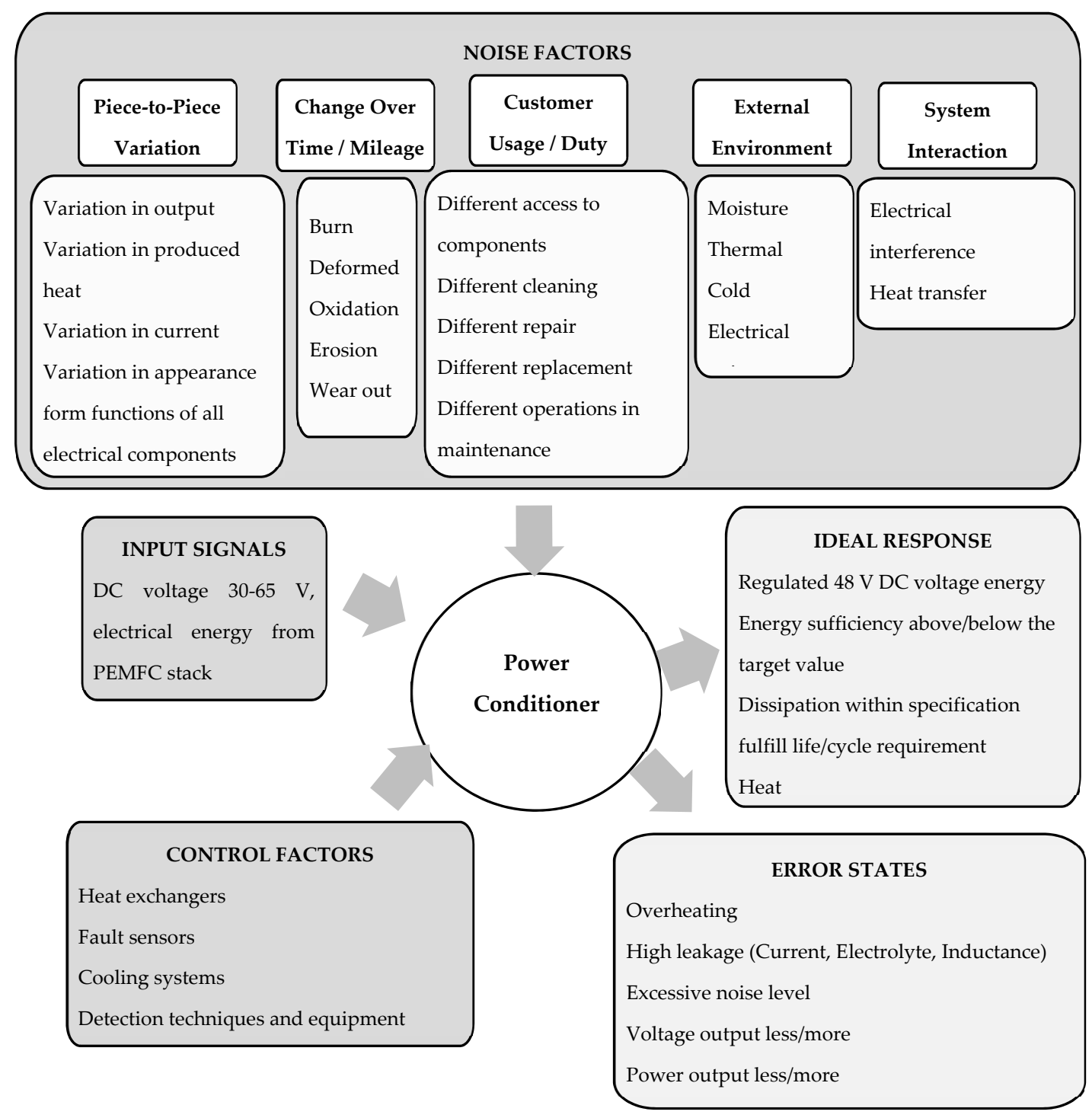

Figure 6. Parameter diagram of the power conditioner. 


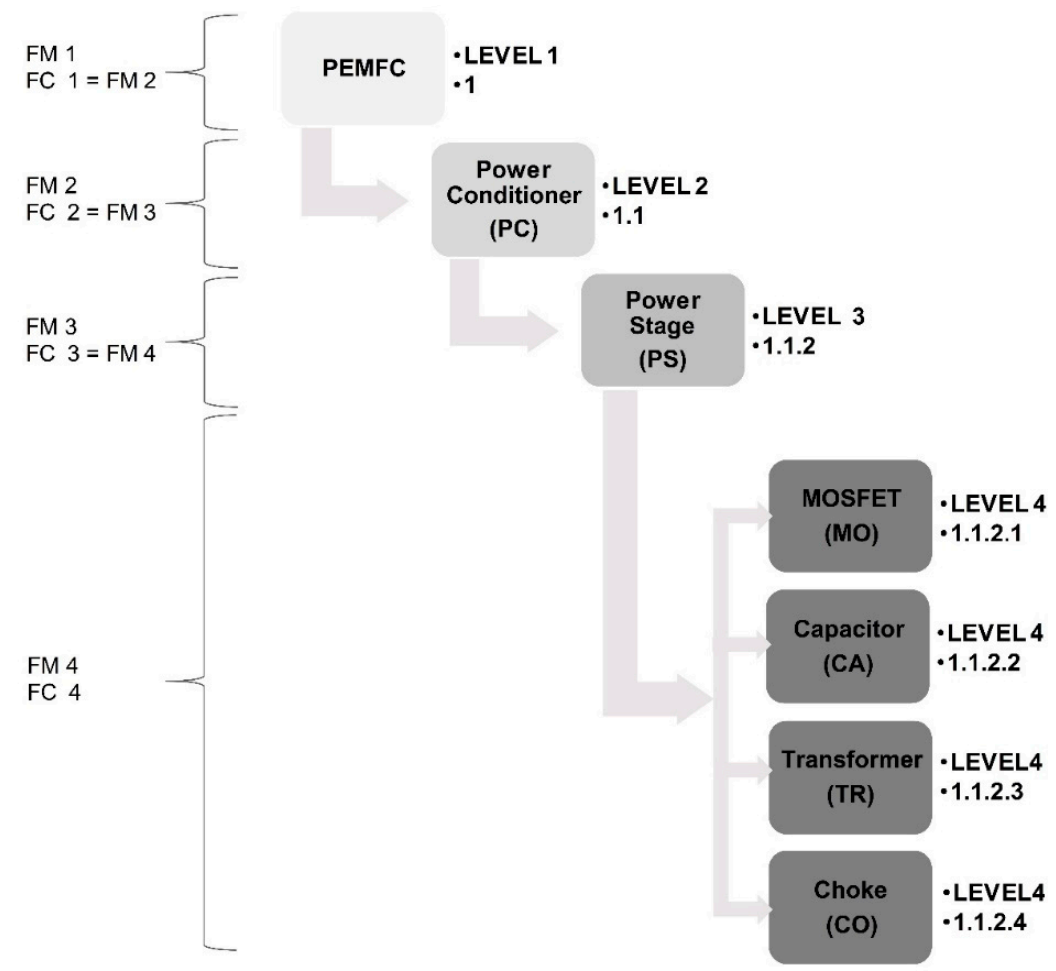

Figure 7. Interfaces between main parts of PEMFC with four levels.

LEVEL 2: Power Conditioner (PC)
LEVEL 3

Power Stage (PS)
LEVEL 4:

Critical Components

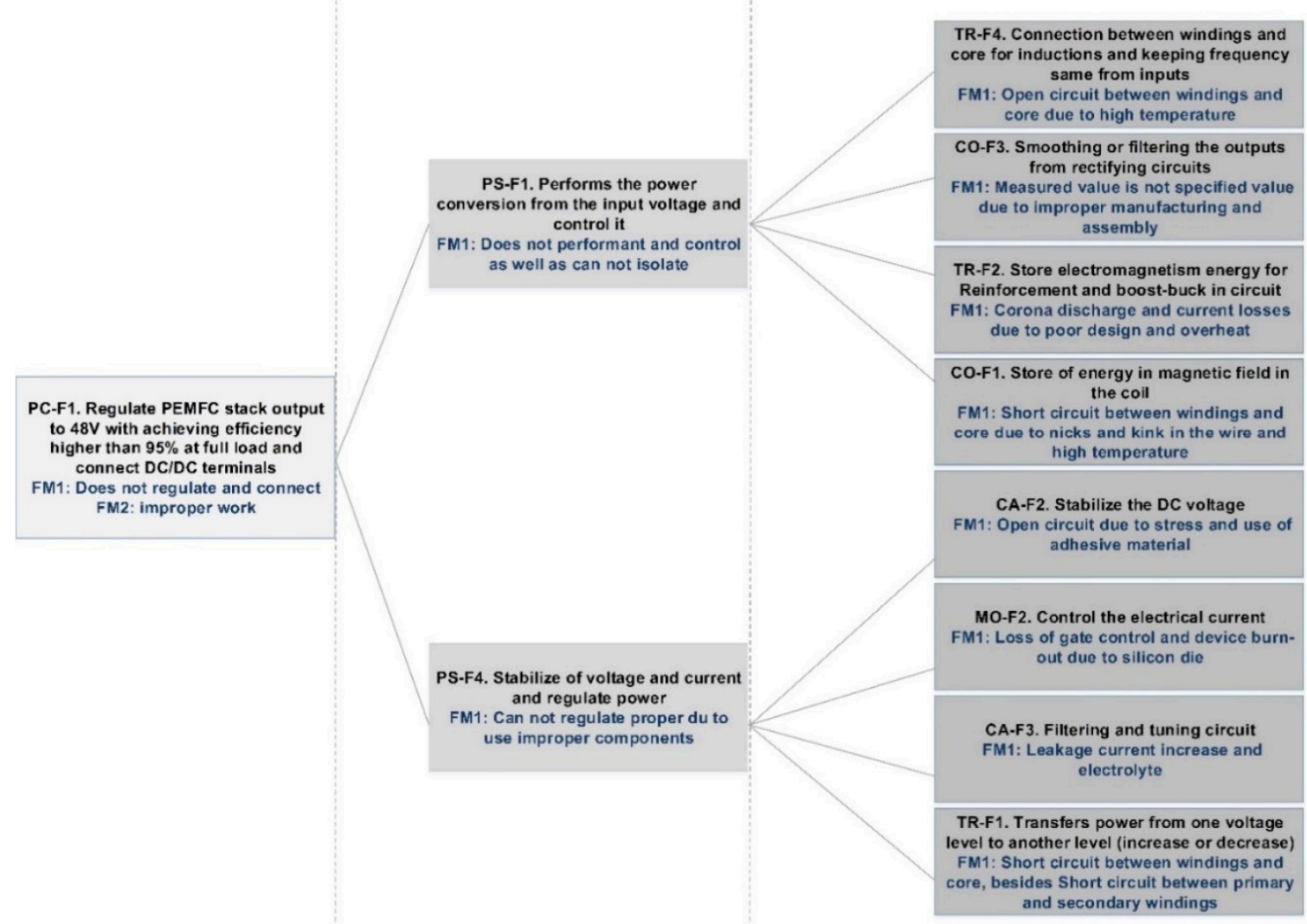

Figure 8. Relationship of functions and failure modes of the system to component levels of the power conditioner (1). 


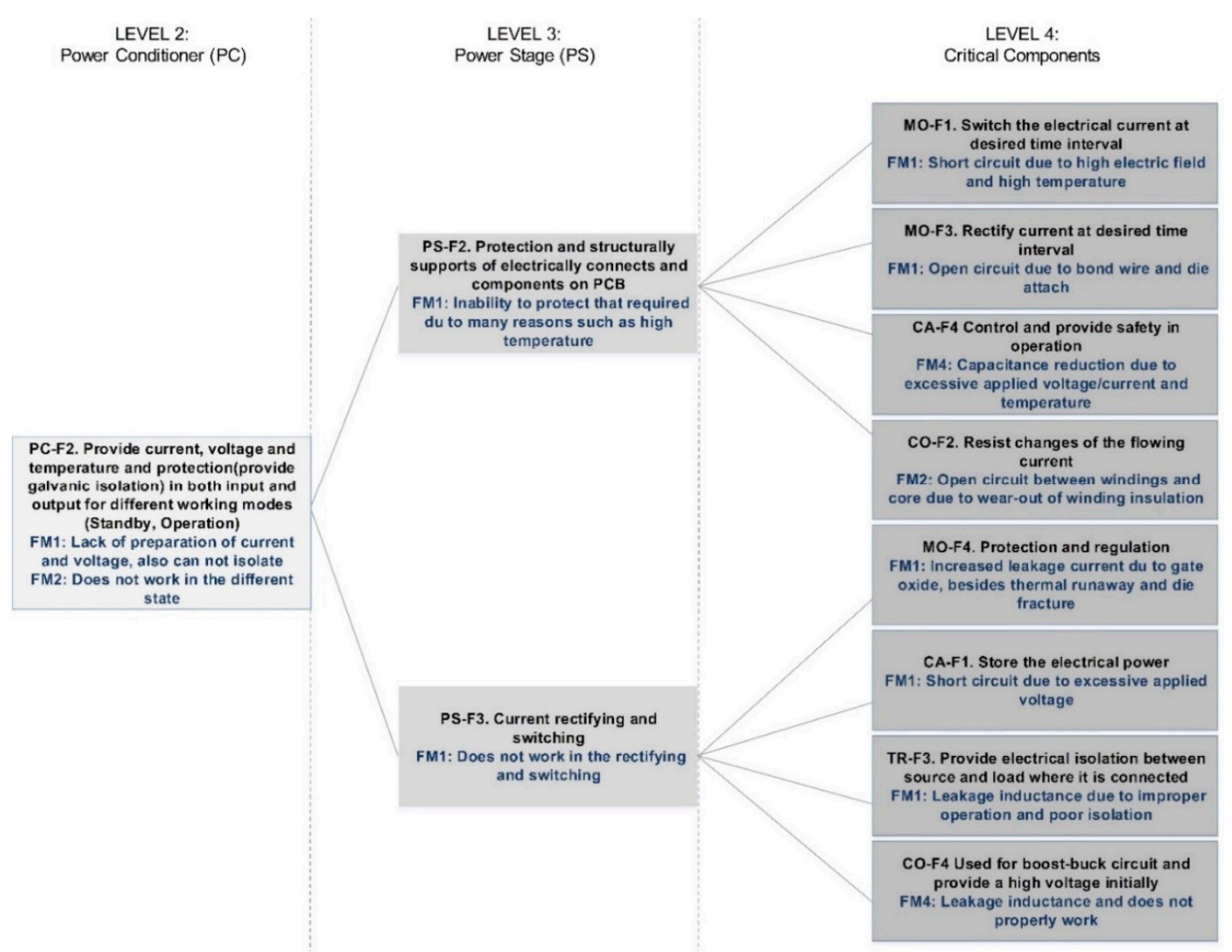

Figure 9. Relationship of functions and failure modes of system till component levels of the power conditioner (2).

\subsection{FMEA Results}

In this paper, a new estimation of the PEMFC system using FMEA is presented by focusing on power electronics components in the power conditioner. The analysis investigates numerous potential failure modes according to the API 580 (American Petroleum Institute), JEDEC (Joint Electron Device Engineering Council), NDI (Non-Destructive Inspection), and normal cause and failure for the industry affections. Specifically, parts of each level may have some failure modes and many failure causes. The failure modes of each level, in fact, are failure causes of the higher level. In the power conditioner, the power stage is identified as the most critical subsystem, and four critical components have the highest risk of failure and damage. Furthermore, the highest RPN is for the MOSFETs and capacitors are respectively having a result of 448, 392 with the failure mode of 'high leakage current due to substrate interface' and 'electrolyte evaporation'. High leakage current failure mode having two main causes, 'high current density' and 'over-voltage' has the highest risk number for the MOSFETs. Moreover, electrolytic evaporation by the deterioration of sealant material leads to insufficient sealing for the capacitors having the highest risk number in passive components. The FMEA of all the components and calculated RPNs for the power stage are illustrated in Table 3. 
Table 3. FMEA table for critical sub-components of the power stage.

\begin{tabular}{|c|c|c|c|c|c|c|c|c|c|}
\hline ID & Item & Function & Failure Mode & Failure Causes & Failure Effects & $\mathrm{s}$ & $\mathbf{O}$ & $\mathbf{D}$ & $\begin{array}{l}\mathbf{R} \\
\mathbf{P} \\
\mathbf{N}\end{array}$ \\
\hline \multirow{12}{*}{ 1.1.2.1 } & \multirow{12}{*}{ MOSFET } & \multirow{3}{*}{$\begin{array}{l}\text { Switch electrical } \\
\text { current at desired time } \\
\text { interval }\end{array}$} & \multirow{3}{*}{$\begin{array}{l}\text { Short circuit, loss of gate control, and } \\
\text { increased leakage current due to gate } \\
\text { oxide }\end{array}$} & High temperature & \multirow{3}{*}{$\begin{array}{l}\text { Time dependent dielectric } \\
\text { breakdown }\end{array}$} & \multirow{3}{*}{9} & \multirow{3}{*}{7} & \multirow{3}{*}{5} & \multirow{3}{*}{315} \\
\hline & & & & High electric field & & & & & \\
\hline & & & & Over-voltage & & & & & \\
\hline & & \multirow{3}{*}{$\begin{array}{l}\text { Control electrical } \\
\text { current }\end{array}$} & \multirow{3}{*}{$\begin{array}{l}\text { High power dissipation, loss of gate } \\
\text { control and device burn-out due to } \\
\text { silicon die }\end{array}$} & High electric field & \multirow{3}{*}{$\begin{array}{l}\text { Latch-up, Increased forward } \\
\text { voltage }\end{array}$} & \multirow{3}{*}{8} & \multirow{3}{*}{7} & \multirow{3}{*}{5} & \multirow{3}{*}{280} \\
\hline & & & & Over-voltage & & & & & \\
\hline & & & & Ionizing radiation & & & & & \\
\hline & & \multirow{4}{*}{$\begin{array}{l}\text { Rectify current at } \\
\text { desired time interval }\end{array}$} & \multirow{4}{*}{$\begin{array}{l}\text { High leakage current due to substrate } \\
\text { interface }\end{array}$} & High temperature & \multirow{4}{*}{ Hot electrons } & \multirow{4}{*}{8} & \multirow{4}{*}{7} & \multirow{4}{*}{8} & \multirow{4}{*}{448} \\
\hline & & & & High current & & & & & \\
\hline & & & & Over-voltage & & & & & \\
\hline & & & & High current density & & & & & \\
\hline & & \multirow{2}{*}{$\begin{array}{l}\text { Protection and } \\
\text { regulation }\end{array}$} & \multirow{2}{*}{$\begin{array}{l}\text { Open circuit due to bond wire and die } \\
\text { attach }\end{array}$} & High temperature & \multirow{2}{*}{$\begin{array}{l}\text { Bond-wire cracking, lift-off; } \\
\text { delamination of die attach }\end{array}$} & \multirow{2}{*}{7} & \multirow{2}{*}{4} & \multirow{2}{*}{6} & \multirow{2}{*}{168} \\
\hline & & & & High current density & & & & & \\
\hline \multirow{8}{*}{ 1.1.2.2 } & \multirow{8}{*}{ Capacitor } & $\begin{array}{l}\text { Store the electrical } \\
\text { power }\end{array}$ & Short circuit between electrodes & $\begin{array}{l}\text { Excessive applied } \\
\text { voltage }\end{array}$ & Unable to store & 9 & 4 & 6 & 216 \\
\hline & & \multirow[b]{2}{*}{ Stabilize the DC voltage } & \multirow[b]{2}{*}{ Open circuit } & Mechanical stress & & & & & \\
\hline & & & & $\begin{array}{c}\text { Use of } \\
\text { adhesive/coating } \\
\text { material }\end{array}$ & $\begin{array}{l}\text { Breakdown of terminal leads } \\
\text { and corrosion }\end{array}$ & 8 & 4 & 8 & 256 \\
\hline & & $\begin{array}{l}\text { Filtering and tuning } \\
\text { circuit }\end{array}$ & Current and electrolyte evaporation & $\begin{array}{l}\text { Deterioration of } \\
\text { sealant material }\end{array}$ & Insufficient sealing & 7 & 7 & 8 & 392 \\
\hline & & & & $\begin{array}{l}\text { Excessive ripple } \\
\text { current }\end{array}$ & & & & & \\
\hline & & Control and provide & & High temperature & foil capacitance reduction, & & & & \\
\hline & & safety in operation & Capacitance reduction & $\begin{array}{l}\text { Excessive applied } \\
\text { voltage }\end{array}$ & $\begin{array}{l}\text { cathode foil capacitance } \\
\text { reduction and deterioration of }\end{array}$ & 7 & 7 & 6 & 294 \\
\hline & & & & $\begin{array}{l}\text { Reverse voltage } \\
\text { applied }\end{array}$ & & & & & \\
\hline
\end{tabular}


Table 3. Cont

\begin{tabular}{|c|c|c|c|c|c|c|c|c|c|}
\hline ID & Item & Function & Failure Mode & Failure Causes & Failure Effects & $\mathrm{s}$ & $\mathbf{O}$ & D & $\begin{array}{l}\mathbf{R} \\
\mathbf{P} \\
\mathbf{N}\end{array}$ \\
\hline \multirow{7}{*}{ 1.1.2.3 } & \multirow{7}{*}{ Transformer } & \multirow{4}{*}{$\begin{array}{l}\text { Increase or decrease } \\
\text { power from one voltage } \\
\text { level to another level }\end{array}$} & \multirow{4}{*}{$\begin{array}{l}\text { Short circuit between windings and } \\
\text { core, besides short circuit between } \\
\text { primary and secondary windings }\end{array}$} & High temperature & \multirow{2}{*}{ Impaired/improper operation } & \multirow{4}{*}{9} & \multirow{4}{*}{4} & \multirow{4}{*}{6} & \multirow{4}{*}{216} \\
\hline & & & & Electrical overstress & & & & & \\
\hline & & & & Poor isolation & \multirow{2}{*}{ Impaired/improper operation } & & & & \\
\hline & & & & $\begin{array}{c}\text { Low dielectric } \\
\text { withstanding voltage }\end{array}$ & & & & & \\
\hline & & $\begin{array}{l}\text { Connection between } \\
\text { windings and core for } \\
\text { induction and keeping } \\
\text { frequency the same }\end{array}$ & $\begin{array}{l}\text { Open circuit between windings and } \\
\text { core }\end{array}$ & High Temperature & Does not connect & 8 & 4 & 6 & 192 \\
\hline & & $\begin{array}{l}\text { Provide electrical } \\
\text { isolation between } \\
\text { source and load where } \\
\text { it is connected }\end{array}$ & Leakage inductance & $\begin{array}{l}\text { Faulty design and } \\
\text { manufacturing } \\
\text { techniques }\end{array}$ & Impaired/improper operation & 5 & 3 & 7 & 105 \\
\hline & & $\begin{array}{l}\text { Store electromagnetism } \\
\text { energy for } \\
\text { reinforcement and } \\
\text { boost-buck in circuit }\end{array}$ & Corona discharge and current losses & Poor design & High heat dissipation & 4 & 4 & 7 & 112 \\
\hline \multirow{8}{*}{ 1.1.2.4 } & \multirow{8}{*}{ Choke } & \multirow{2}{*}{$\begin{array}{l}\text { Store of energy in } \\
\text { magnetic field in the } \\
\text { coil }\end{array}$} & \multirow{2}{*}{$\begin{array}{l}\text { Short circuit between windings and } \\
\text { core }\end{array}$} & $\begin{array}{l}\text { Nicks and kink in } \\
\text { the wire }\end{array}$ & \multirow[t]{2}{*}{ Does not connect } & \multirow[t]{2}{*}{9} & \multirow[t]{2}{*}{3} & \multirow[t]{2}{*}{7} & \multirow[t]{2}{*}{189} \\
\hline & & & & High temperature & & & & & \\
\hline & & \multirow{2}{*}{$\begin{array}{l}\text { Resist changes of the } \\
\text { flowing current }\end{array}$} & \multirow{2}{*}{$\begin{array}{l}\text { Open circuit between windings and } \\
\text { core }\end{array}$} & Thermal overstress & \multirow{2}{*}{ Limited or not operation } & \multirow{2}{*}{8} & \multirow{2}{*}{4} & \multirow{2}{*}{6} & \multirow{2}{*}{192} \\
\hline & & & & $\begin{array}{l}\text { Wear-out of winding } \\
\text { insulation }\end{array}$ & & & & & \\
\hline & & \multirow{3}{*}{$\begin{array}{l}\text { Smoothing or filtering } \\
\text { the outputs from the } \\
\text { rectifying circuits }\end{array}$} & \multirow{3}{*}{$\begin{array}{l}\text { Measured value is not the specified } \\
\text { value }\end{array}$} & $\begin{array}{c}\text { Manufacturing } \\
\text { defect }\end{array}$ & \multirow{3}{*}{ Improper operation } & \multirow{3}{*}{7} & \multirow{3}{*}{3} & \multirow{3}{*}{7} & \multirow{3}{*}{147} \\
\hline & & & & $\begin{array}{c}\text { Improper } \\
\text { assembly/soldering }\end{array}$ & & & & & \\
\hline & & & & $\begin{array}{l}\text { Faulty layout and } \\
\text { mounting of } \\
\text { components }\end{array}$ & & & & & \\
\hline & & $\begin{array}{l}\text { Use boost-buck circuit } \\
\text { and provide a high } \\
\text { initial voltage }\end{array}$ & $\begin{array}{l}\text { Inductance leakage and does not } \\
\text { properly work }\end{array}$ & $\begin{array}{l}\text { Overload and } \\
\text { overstress }\end{array}$ & Does not function properly & 6 & 4 & 7 & 168 \\
\hline
\end{tabular}


According to Table 3, the highest RPNs are seen and depicted clearly in Figure 10. Furthermore, by analyzing the output of the FMEA, the top failure modes are distinguished depending on the severity, concurrency, and detection rate. It is valuable to point out that the uppermost of risk priorities of failure modes requiring the severity parameter as well as occurrence rate refers to the short circuit in each of the four main components having an overstressed mechanism. Moreover, all leakages in the components such as leakage current in MOSFETs, electrolyte evaporation in capacitors and leakage inductance in inductors as well as transformers have the highest risk priorities of failure modes. This issue should be considered in order to reduce the risk by improving the design.

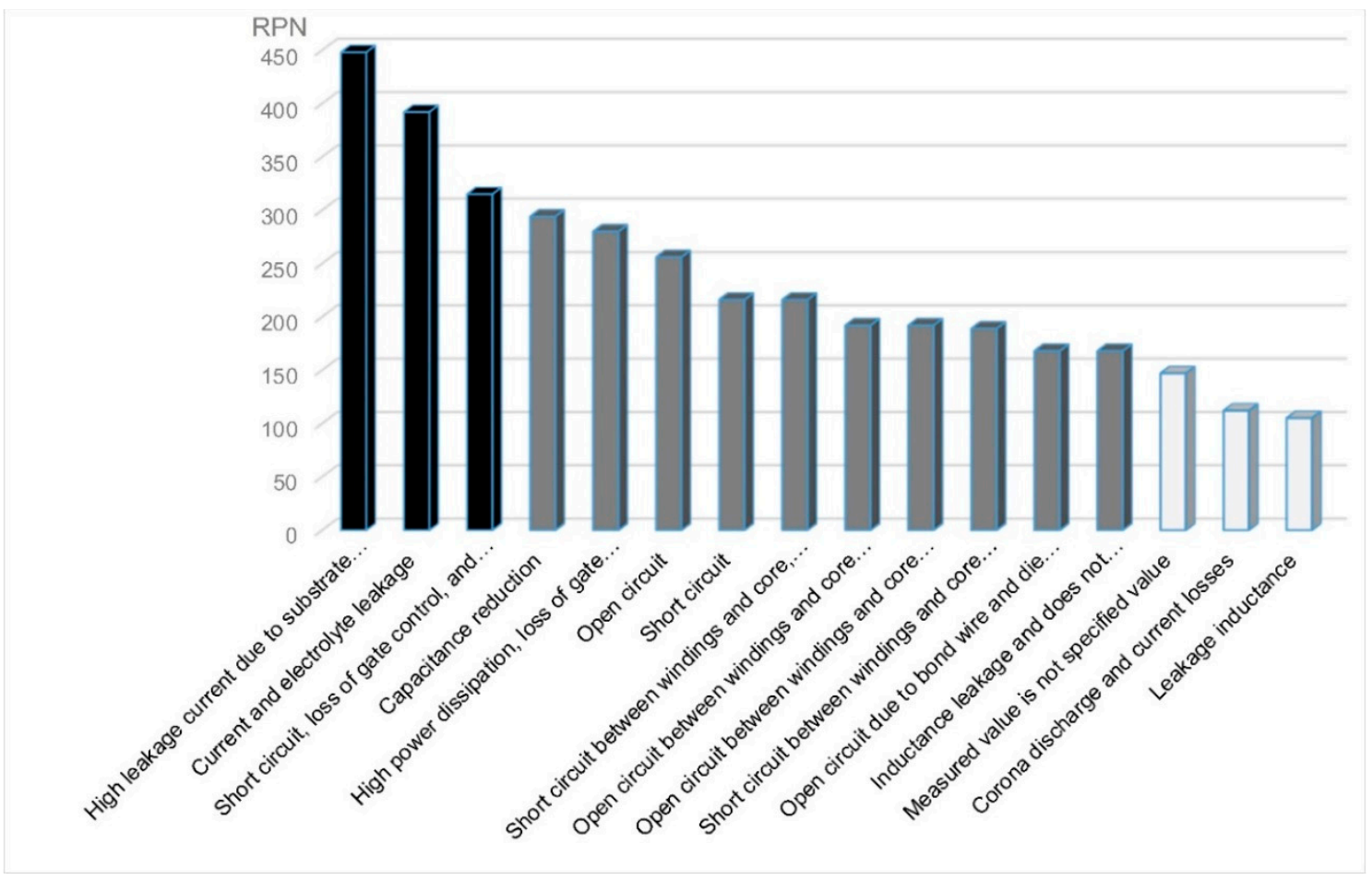

Figure 10. Pareto plot of RPNs for each failure mode analyzed in Table 3.

\section{Risk Analysis}

Risk analysis is one of the most rational methods to identify failure modes in fuel cell systems. The risk analysis using FMEA is an approach to prioritize the potential risk according to the failure causes [28]. In this risk analysis, the MOSFET having four main failure modes, and at least two causes for each one and average RPN $=303$ in the power stage have the highest risk. Additionally, the capacitor item having four main failure modes and more than ten causes and average RPN $=274$ is more critical compared to the inductor item having four main failure modes and six different causes and average RPN = 176. Finally, the transformer having four main failure modes, and six main causes has an average of $\mathrm{RPN}=163$.

Figure 10 illustrates three areas of critically failure modes for the crucial components of the power stage. The black color is considered for above 300 RPNs, and below 150 RPNs are colored with white. Most failure modes are in the medium range of risk, and they are shown with gray color. Extensive simulation studies, preventive control, use of diagnostic methods, predictive deployment technologies, employing visual management techniques, using sensors to distinguish failures, using preventive maintenance and developing inspection methods to identify hidden failures in the redundant items are among the recommended implementations for any of the components in the PEMFC system. 


\section{Bayesian Network}

In a Bayesian analysis, the probability $P(A)$ of the event $A$ is formulated as a degree of belief that A will occur [29].

Bayesian network (BN) refers to Bayes rule, given the event ' $B$ ', the probability of event ' $A$ ' is $[P(A \mid B)]$

$$
P(A \mid B)=\frac{1}{P(B)} P(B \mid A) P(A),
$$

where $P(A)$ is a prior estimate, $P(B \mid A)$ is a likelihood of $A$ given $B$, and $P(B)$ is the marginal probability of $B[30]$.

In order to build a BN based on the available FMEA, following BN is suggested:

In Figure 11, it is shown in an illustrative way how BN is built from the FMEA (Table 3) [31]. Finally, by merging common nodes, the BN for MOSFET is created as shown in Figure 12. The reason to choose the MOSFET is because of the results obtained from RPN. As shown in Figure 10, the first failure mode has the most significant influence on the system. The aim is to find, which failure cause has the most impact. Hugin as a tool is used for building the BN. It is considered that each node has two states, true and false.

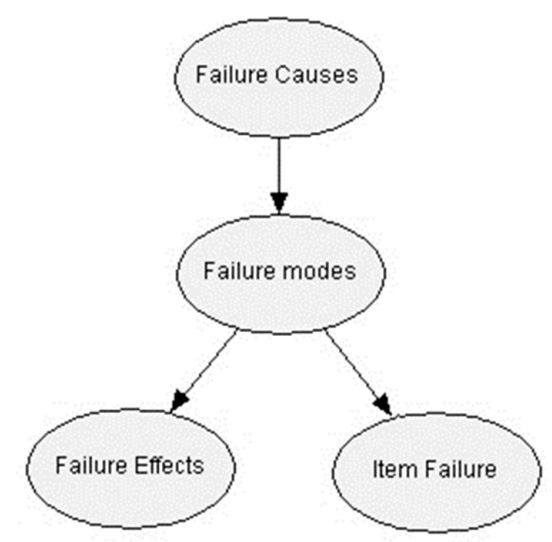

Figure 11. From FMEA to BN.

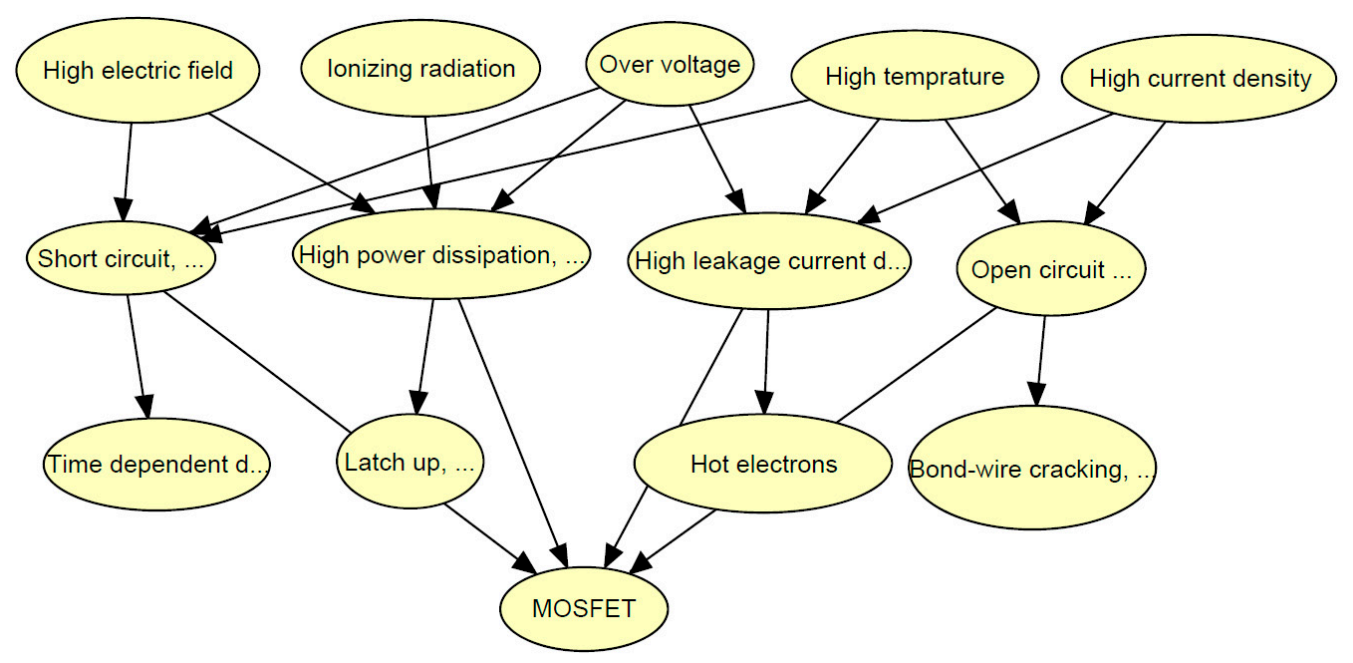

Figure 12. BN for the MOSFET.

The aim is to find the most significant failure cause in the failure of MOSFET by BN. From FMEA and Figure 10, high leakage current due to substrate interface is identified having the highest RPN which is one of the failure modes of MOSFET. Hence, MOSFET is analyzed to recognize the most important failure cause. 
The process of making the $\mathrm{BN}$ is as follows:

1. BN is built based on Figure 11. from the FMEA in Table 3;

2. Joint failure modes and causes are merged;

3. For all failure causes two states are defined with equal probability of failure for their states: false and true;

4. Conditional probability tables (CPTs) are built. The maximum entropy theory is used to specify each probability of failure. Figure 13 shows two examples of conditional probability tables (CPTs).

High leakage current due to substrate interface

\begin{tabular}{|c|c|c|c|c|c|c|c|c|}
\hline Over voltage & \multicolumn{4}{|c|}{ false } & \multicolumn{4}{|c|}{ true } \\
\hline High temprature & \multicolumn{2}{|c|}{ false } & \multicolumn{2}{|c|}{ true } & \multicolumn{2}{|c|}{ false } & \multicolumn{2}{|c|}{ true } \\
\hline High current density & false & true & false & true & false & true & false & true \\
\hline false & 1 & 0.66 & 0.66 & 0.34 & 0.66 & 0.34 & 0.34 & 0 \\
\hline true & 0 & 0.34 & 0.34 & 0.66 & 0.34 & 0.66 & 0.66 & 1 \\
\hline
\end{tabular}

Open circuit due to bond wire

\begin{tabular}{|l|l|l|l||c||c|}
\hline High current density & \multicolumn{2}{|c|}{ false } & \multicolumn{2}{c|}{ true } \\
\hline \multicolumn{1}{|c|}{ High temprature } & \multicolumn{1}{|c|}{ false } & \multicolumn{2}{c|}{ true } & \multicolumn{2}{c|}{ false } \\
\hline false & 1 & 0.5 & 0.5 & 0 \\
\hline true & 0 & 0.5 & 0.5 & 1 \\
\hline
\end{tabular}

Figure 13. Two examples of conditional probability tables (CPTs).

The importance analysis is carried out by assigning each failure cause as false or fail to find the probability of failure of the MOSFET. Figure 14 shows high temperature as an example of one of the failure causes.

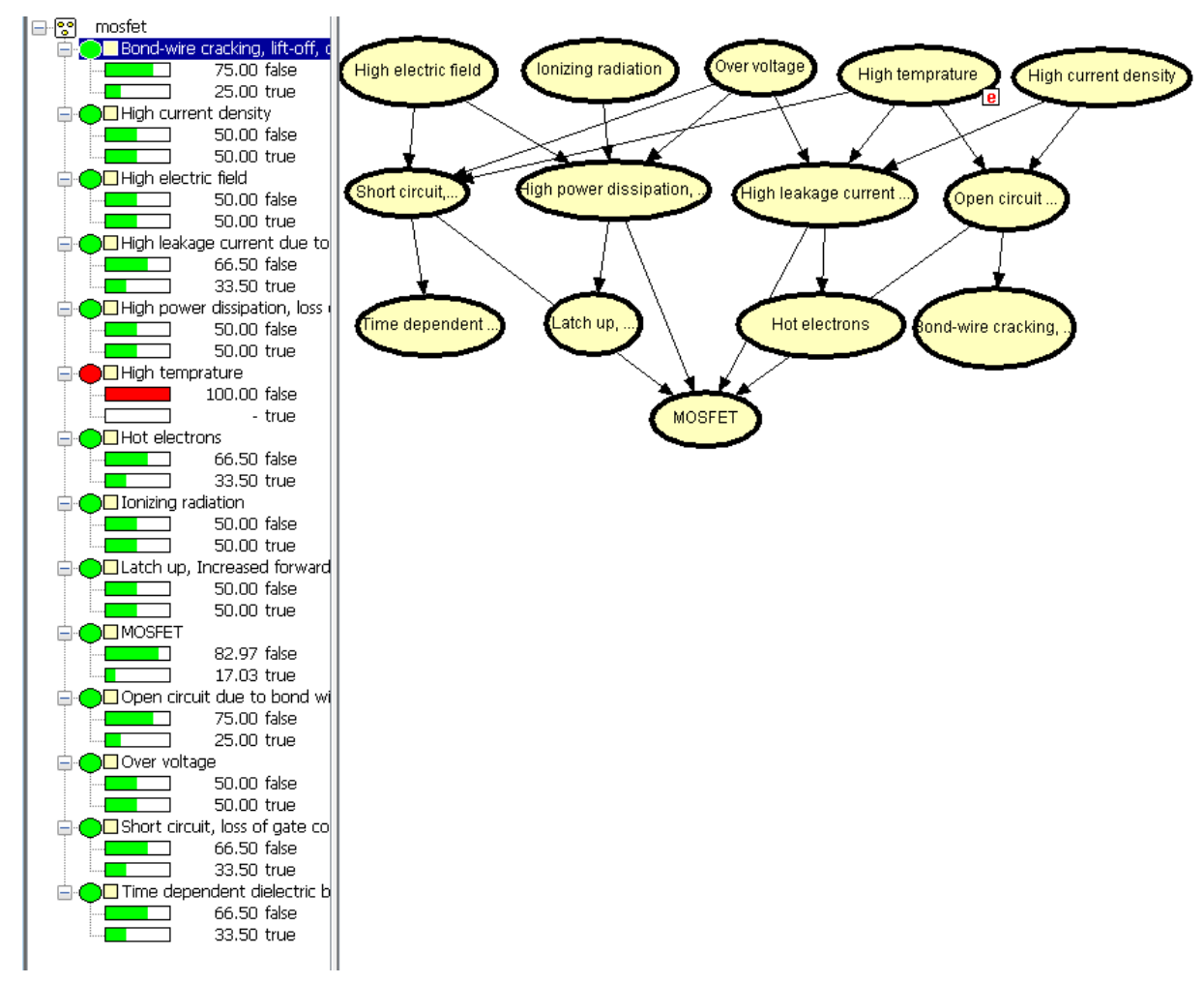

Figure 14. High temperature effect failure on the MOSFET. 
Effect of each failure cause to MOSFET is calculated by the proposed BN. Table 4 compares failure causes in the MOSFET.

Table 4. Comparison of failure causes in the MOSFET.

\begin{tabular}{cc}
\hline Failure Cause & MOSFET Probability of Failure (\%) \\
\hline High Temperature & 82.97 \\
Over Voltage & 79.78 \\
High Current Density & 77.00 \\
High Electric Field & 73.93 \\
Ionizing Radiation & 68.67 \\
\hline
\end{tabular}

Comparing all failure causes effects on MOSFET failure shows that high temperature and overvoltage are the most important failure causes in MOSFET.

\section{Conclusions}

This study proposes a system engineering approach using FMEA for the risk analysis of the power conditioner in a PEMFC system. The highest RPNs correspond to the failure modes in three components, including high leakage current due to the substrate interface of the MOSFET, current and electrolytic evaporation of capacitor, and thereby short circuit, loss of gate control, and increased leakage current due to gate oxide of the MOSFET. Electronic components have a wide range of failure modes. The MOSFETs, capacitors, chokes, and transformers are the critical components of the power stage, which should be carefully considered in the development and implementation stage. In general, short circuit, open circuit, and leakage current are considered as the most important failure modes in the power supply system. Consequently, using a comprehensive FMEA analysis especially by using an extensive P-diagram, failure analysis, and its effects is studied in order to have a better understanding of the system in comparison with the available literature. Finally, BN is used to analyze the most critical failure causes among more important items identified from the FMEA, MOSFET and capacitor. The reason to use $\mathrm{BN}$ is that it was difficult to find RPNs of each failure cause, so the BN is implemented by two states of true and false or in other words failure and success to find the most critical failure cause. High temperature and overvoltage are ascertained utilizing BN. Knowing this fact will help designers to pay more attention on material properties to avoid failure causing by high temperature and overvoltage.

Author Contributions: The main idea for the paper was proposed by S.R. and S.B. wrote the first draft of the paper. S.R. and S.B. developed the methodology. S.R. and S.B. post-processed the results. D.Z., H.W., F.B. and J.D.S. supervised the findings of this work and reviewed methodology and results. All authors contributed for articulate the research work in its current form as full research manuscript. All authors have read and agreed to the published version of the manuscript.

Funding: The paper presents research results from the Marie Skłodowska-Curie Innovative Training Network INFRASTAR in the field of reliability approaches for decision-making for wind turbines and bridges. The project INFRASTAR (infrastar.eu) has received funding from the European Union's Horizon 2020 research and innovation program under the Marie Skłodowska-Curie grant agreement No. 676139. The grant is gratefully acknowledged.

Conflicts of Interest: The authors declare no conflict of interest.

\section{References}

1. Barbir, F. Front Matter. In PEM Fuel Cells; Elsevier: Amsterdam, The Netherladns, 2013; p. iii. ISBN 9780123877109.

2. Zawodzinski, T.A. PEM fuel cells: How things work. ACS Div. Fuel Chem. Prepr. 2004, 49, 470.

3. Wu, J.; Yuan, X.Z.; Martin, J.J.; Wang, H.; Zhang, J.; Shen, J.; Wu, S.; Merida, W. A review of PEM fuel cell durability: Degradation mechanisms and mitigation strategies. J. Power Sources 2008, 184, 104-119. [CrossRef] 
4. Krishnan, K.J.; Kalam, A.; Zayegh, A. Experimental investigation of H2 generator and PEM fuel cell as a remote area back-up power. Procedia Eng. 2012, 49, 66-73. [CrossRef]

5. Modarres, M. Risk Analysis in Engineering: Techniques, Tools, and Trends; CRC Press: Boca Raton, FL, USA, 2006.

6. Rastayesh, S.; Bahrebar, S.; Sepanloo, K. Time Dependent Reliability of Emergency Diesel Generator Station. Indian J. Sci. Res. 2014, 1, 453-460.

7. Bahrebar, S.; Rastayesh, S.; Sepanloo, K. Dynamic Availability Assessment on Tehran Research Reactor Water Cooling System. Indian J. Sci. Res. 2014, 1, 471-474.

8. Rastayesh, S.; Bahrebar, S. Importance Analysis of a Typical Diesel Generator Using Dynamic Fault Tree. Int. J. Curr. Life Sci. 2014, 4, 697-700.

9. Rastayesh, S.; Long, L.; Sørensen, J.D.; Thöns, S. Risk Assessment and Value of Action Analysis for Icing Conditions of Wind Turbines Close to Highways. Energies 2019, 12, 2653. [CrossRef]

10. Modarres, M.; Kaminskiy, M.; Krivtsov, V. Reliability Engineering and Risk Analysis: A Practical Guide, 3rd ed.; CRC Press: Boca Raton, FL, USA, 2010.

11. Barends, D.M.; Oldenhof, M.T.; Vredenbregt, M.J.; Nauta, M.J. Risk analysis of analytical validations by probabilistic modification of FMEA. J. Pharm. Biomed. Anal. 2012, 64-65, 82-86. [CrossRef]

12. Narayanagounder, S.; Gurusami, K. A New Approach for Prioritization of Failure Modes in Design FMEA using ANOVA. World Acad. Sci. Eng. Technol. 2009, 3, 524-531.

13. Rhee, S.J.; Ishii, K. Using cost based FMEA to enhance reliability and serviceability. Adv. Eng. Inform. 2003, 17, 179-188. [CrossRef]

14. Arabian-Hoseynabadi, H.; Oraee, H.; Tavner, P.J. Failure Modes and Effects Analysis (FMEA) for wind turbines. Int. J. Electr. Power Energy Syst. 2010, 32, 817-824. [CrossRef]

15. Kim, K.O.; Zuo, M.J. General model for the risk priority number in failure mode and effects analysis. Reliab. Eng. Syst. Saf. 2018, 169, 321-329. [CrossRef]

16. Whiteley, M.; Dunnett, S.; Jackson, L. Failure Mode and Effect Analysis, and Fault Tree Analysis of Polymer Electrolyte Membrane Fuel Cells. Int. J. Hydrogen Energy 2016, 41, 1187-1202. [CrossRef]

17. Benmouna, A.; Becherif, M.; Depernet, D.; Gustin, F.; Ramadan, H.S.; Fukuhara, S. Fault diagnosis methods for Proton Exchange Membrane Fuel Cell system. Int. J. Hydrogen Energy 2017, 42, 1534-1543. [CrossRef]

18. Nielsen, J.J.; Sørensen, J.D. Bayesian Networks as a Decision Tool for O\&M of Offshore Wind Turbines. In ASRANet, Proceedings of the Integrating Stuctural Analysis, Risk E Reliability: 5th International ASRANet Conference, Edinburgh, UK, 14-16 June 2010; ASRANet Ltd.: Glasgow, UK, 2010.

19. Trukhanov, S.V.; Troyanchuk, I.O.; Trukhanov, A.V.; Fita, I.M.; Vasil'ev, A.N.; Maignan, A.; Szymczak, H. Magnetic properties of $\mathrm{La} 0.70 \mathrm{Sr} 0.30 \mathrm{MnO} 2.85$ anion-deficient manganite under hydrostatic pressure. JETP Lett. 2006, 83, 33-36. [CrossRef]

20. Trukhanov, S.V.; Trukhanov, A.V.; Turchenko, V.A.; Trukhanov, A.V.; Tishkevich, D.I.; Trukhanova, E.L.; Zubar, T.I.; Karpinsky, D.V.; Kostishyn, V.G.; Panina, L.V.; et al. Magnetic and dipole moments in indium doped barium hexaferrites. J. Magn. Magn. Mater. 2018, 457, 83-96. [CrossRef]

21. Trukhanov, A.V.; Grabchikov, S.S.; Solobai, A.A.; Tishkevich, D.I.; Trukhanov, S.V.; Trukhanova, E.L. AC and DC-shielding properties for the Ni80Fe20/Cu film structures. J. Magn. Magn. Mater. 2017, 443, 142-148. [CrossRef]

22. Arpaia, P.; Buzio, M.; Capatina, O.; Eiler, K.; Langeslag, S.A.E.; Parrella, A.; Templeton, N.J. Effects of temperature and mechanical strain on Ni-Fe alloy CRYOPHY for magnetic shields. J. Magn. Magn. Mater. 2019, 475, 514-523. [CrossRef]

23. Zhang, J. PEM Fuel Cell Electrocatalysts and Catalyst Layers: Fundamentals and Applications; Springer Science \& Business Media: Berlin/Heidelberg, Germany, 2008; ISBN 9781848009356.

24. Zhou, D.; Wang, H.; Blaabjerg, F.; Kor, S.K.; Blom-Hansen, D. System-level reliability assessment of power stage in fuel cell application. In Proceedings of the 2016 IEEE Energy Conversion Congress and Exposition (ECCE), Milwaukee, WI, USA, 18-22 September 2016; pp. 1-8.

25. Bahrebar, S.; Zhou, D.; Rastayesh, S.; Wang, H.; Blaabjerg, F. Reliability assessment of power conditioner considering maintenance in a PEM fuel cell system. Microelectron. Reliab. 2018, 88-90, 1177-1182. [CrossRef]

26. Zhou, D.; Wang, H.; Blaabjerg, F. Mission Profile Based System-Level Reliability Analysis of DC/DC Converters for a Backup Power Application. IEEE Trans. Power Electron. 2018, 33, 8030-8039. [CrossRef] 
27. Jensen, F.; Morris, A.S.; Levin, M.A.; Kalal, T.T.; Pascoe, N.; Carlson, C. Effective FMEAs; Wiely: Hoboken, NJ, USA, 2012.

28. Rastayesh, S.; Bahrebar, S.; Bahman, A.S.; Sørensen, J.D.; Blaabjerg, F. Lifetime Estimation and Failure Risk Analysis in a Power Stage Used in Wind-Fuel Cell Hybrid Energy Systems. Electronics 2019, 8, 1412. [CrossRef]

29. Faber, M.H. Statistics and Probability Theory; Topics in Safety, Risk, Reliability and Quality; Springer: Dordrecht, The Netherlands, 2012; Volume 18, ISBN 978-94-007-4055-6.

30. Kjaerulff, U.B.; Madsen, A.L. Bayesian Networks and Influence Diagrams: A Guide to Construction and Analysis; Springer: New York, NY, USA, 2008; ISBN 9780387741017.

31. Hamza, Z.; Abdallah, T. Mapping Fault Tree into Bayesian Network in safety analysis of process system. In Proceedings of the 2015 th International Conference on Electrical Engineering (ICEE), Bounerdes, Algeria, 13-15 December 2015; pp. 1-5.

(C) 2019 by the authors. Licensee MDPI, Basel, Switzerland. This article is an open access article distributed under the terms and conditions of the Creative Commons Attribution (CC BY) license (http://creativecommons.org/licenses/by/4.0/). 